\title{
Hypoxia Inducible Factor (HIF) 1-A dan Vascular Endothelial Growth Factor (VEGF) pada Stroke Iskemik Fase Akut
}

\author{
Lisda Amalia*), Ida Parwati**), Ahmad Rizal ${ }^{*}$, Ramdan Panigoro ${ }^{* * *}$, Uni Gamayani*), Al Rasyid ${ }^{* * * *}$, Nur \\ Atik $\left.^{* * *}\right)$ \\ ${ }^{*}$ Departemen Neurologi, Fakultas Kedokteran, Universitas Padjadjaran Bandung, ${ }^{* *}$ Departemen Patologi Klinik, \\ Fakultas Kedokteran, Universitas Padjadjaran Bandung, ${ }^{* * *}$ Departemen Ilmu Kedokteran Dasar, Fakultas \\ Kedokteran, Universitas Padjadjaran, Bandung, Indonesia, ${ }^{* * *}$ Departemen Neurologi, Fakultas Kedokteran, \\ Universitas Indonesia, Jakarta, Indonesia
}

\begin{abstract}
Abstrak
Stroke iskemik merupakan salah satu penyebab stroke tersering, disebabkan oleh oklusi pembuluh darah serebral dan penyebab kematian ketiga. Saat awitan stroke iskemik terjadi, area otak yang diperdarahi oleh pembuluh darah akan kekurangan oksigen dan nutrisi sehingga sel otak terutama neuron berada dalam risiko, neuron ini masih dapat berfungsi yang dikenal sebagai penumbra. Hipoksik, salah satu karakteristik penumbra merupakan stimulus utama regulasi protein HIF-1 $\alpha$. Hipoksik sendiri merupakan stimulus utama prekondisi iskemik. Prekondisi iskemik akan menghasilkan fenotipe tahan hipoksia yakni protein hypoxia inducible factor (HIF)-1 $\alpha$. HIF-1 $\alpha$ merupakan satusatunya zat yang dikeluarkan oleh jaringan yang mengalami hipoksia. HIF-1 $\alpha$ bertindak sebagai protein sinyal yang dapat meregulasi gen protein lain. Efektor HIF-1 $\alpha$ antara lain eritropoitin dan vascular endothelial growth factor (VEGF). Pertumbuhan, diferensiasi dan ketahanan sel endotel diregulasi oleh VEGF yang distimulasi dari HIF-1 $\alpha$. Selama iskemik serebral, jaringan yang rusak mencoba untuk meningkatkan pengiriman oksigen melalui induksi angiogenesis melalui produksi VEGF. Hal ini ditandai dengan adanya peningkatan jumlah pembuluhpembuluh darah mikro di area infark. VEGF dan reseptornya diregulasi oleh HIF-1 $\alpha$ dalam hari pertama iskemik.
\end{abstract}

Kata kunci: stroke iskemik akut; HIF-1 $\alpha$; luaran klinis; VEGF

JNI 2019; 8 (3): 226-32

\section{Hypoxia Inducible Factor (HIF) 1-A and Vascular Endothelial Growth Factor (VEGF) in Acute Ischemic Stroke}

\begin{abstract}
Ischemic stroke is one of the most common causes of stroke, caused by cerebral vascular occlusion and the third cause of death. When the onset of an ischemic stroke occurs, the area of the brain bleeding by blood vessels will lack oxygen and nutrients so that brain cells, especially neurons, are at risk, these neurons can still function known as penumbra. Hypoxic, one of the characteristics of penumbra is the main stimulus for regulation of HIF-1 $\alpha$ protein. Hypoxia itself is the main stimulus of ischemic precondition. The ischemic precondition will produce a hypoxic-resistant phenotype namely protein hypoxia inducible factor (HIF) $-1 \alpha$. HIF-1 1 is the only substance released by tissue that experiences hypoxia. HIF- $1 \alpha$ acts as a signaling protein that can regulate other protein genes. Effectors of HIF-1 ainclude erythropoitin and vascular endothelial growth factor (VEGF). Growth, differentiation and endurance of endothelial cells are regulated by VEGF stimulated from HIF-1 $\alpha$. During cerebral ischemia, damaged tissue tries to increase oxygen delivery through induction of angiogenesis through VEGF production. This is characterized by an increase in the number of micro blood vessels in the infarct area. VEGF and its receptors are regulated by HIF-1 $\alpha$ in the first day of ischemia.
\end{abstract}

Key words: acute ischemic stroke; clinical outcome; HIF-1 $\alpha$; VEGF

JNI 2019; 8 (3): 226-32 


\section{Pendahuluan}

Stroke merupakan penyebab kematian tertinggi ketiga di dunia dan pertama di Asia, negaranegara Association of South East Asian Nations (ASEAN), dan di Indonesia. Di Indonesia, stroke menyumbang $15,4 \%$ dari seluruh kematian. Selain merupakan penyebab tertinggi kematian, stroke juga merupakan penyebab disabilitas tertinggi di Indonesia. ${ }^{1}$ Stroke iskemik merupakan salah satu penyebab stroke tersering, disebabkan oleh oklusi pembuluh darah serebral.1 Aterosklerosis merupakan awal mula terjadinya proses trombosis. Hipertensi, diabetes melitus, dislipidemia dan faktor risiko vaskular lain akan menambah luas lesi aterosklerosis. ${ }^{2}$ Area di luar necrotic core masih mendapatkan aliran darah serebral walaupun jumlahnya tidak adekuat (15-25 ml/100 gram jaringan otak). Area ini dinamakan penumbra. Penumbra merupakan area secara fungsional tidak aktif, tetapi dapat kembali normal jika terdapat reperfusi. ${ }^{3}$ Luas penumbra tergantung kepada lokasi oklusi, semakin proksimal, penumbra akan semakin besar dan ukuran pembuluh darah, semakin besar ukuran pembuluh darah maka penumbra akan semakin besar. Penumbra merupakan area yang dapat diselamatkan sehingga banyak usaha yang dilakukan untuk menyelamatkan penumbra seperti trombolisis intravena dan endovascular, bahkan otak sendiri berusaha membuat sebuah keadaan prekondisi iskemik untuk meningkatkan ketahanan sel neuron dan glia dalam keadaan hipoksia. ${ }^{4,5}$

Hipoksik, salah satu karakteristik penumbra merupakan stimulus utama regulasi protein HIF1 $\boldsymbol{\alpha}$. Hypoxia-inducible factor (HIF) merupakan sebuah kompleks protein yang diaktivasi oleh tekanan oksigen rendah. Protein ini berperan dalam berbagai proses fisiologis seperti angiogenesis, eritropoesis dan metabolisme selular yang bertujuan untuk meningkatkan pengiriman oksigen ke dalam jaringan. HIF$1 \boldsymbol{\alpha}$ bertindak sebagai protein sinyal yang dapat meregulasi gen protein lain. ${ }^{6,710}$ Efektor HIF1 aantara lain eritropoitin dan vascular endothelial growth factor (VEGF) ${ }^{8}$ Kedua protein sangat diperlukan untuk mendorong proses angiogenesis dan pembentukan pembuluh darah kolateral yang berguna untuk rekanalisasi. Selain itu HIF-1 $\alpha$ juga berfungsi untuk mengatur tonus pembuluh darah dengan tujuan untuk meningkatkan aliran darah serebral melalui aktivasi enzim nitrit oksida. HIF-1 $\alpha$ dapat mengoptimalkan utilisasi glukosa intraselular dengan meningkatkan transportasi glukosa via aktivasi glucose transporter (GLUT). ${ }^{9}$ Keseluruhan target HIF$1 \alpha$ adalah untuk mengurangi proses apoptosis dan meningkatkan ketahanan sel. HIF-1 $\alpha$ disekresikan pada beberapa jam pasca awitan iskemik dan dapat bertahan sampai tujuh hari. Dalam dua puluh empat jam pertama akumulasi HIF-1 $\alpha$ akan tetap stabil. Sekresi HIF-1 $\alpha$ dalam tujuh hari pertama awitan stroke iskemik, yang juga merupakan fase kritis stroke iskemik dapat memberikan gambaran tentang peranan HIF-1 $\alpha$ pada stroke iskemik, sehingga nantinya akan dapat digunakan sebagai salah satu prediktor keluaran stroke iskemik. ${ }^{10}$

\section{Mekanisme Endogen Otak terhadap Hipoksia}

Otak dapat memiliki mekanisme endogen yang mampu bertahan dari serangan kerusakan iskemik. Jalur pertahanan (survival) alamiini dapat diaktivasi oleh keadaan yang dikenal sebagai prekondisi, dimana pajanan terhadap stresor non injury mencetuskan perubahan ekspresi gen dan protein dan membuat fenotipe yang toleran terhadap iskemik. ${ }^{6,7}$

Hypoxia-inducible factor (HIF) merupakan sebuah kompleks protein yang diaktivasi oleh tekanan oksigen rendah. Protein ini berperan dalam berbagai proses fisiologis seperti angiogenesis, eritropoesis dan metabolisme selular yang bertujuan untuk meningkatkan pengiriman oksigen ke dalam jaringan. Hipoksia, atau suatu kondisi kurangnya oksigen dapat terjadi dalam berbagai macam kondisi seperti pada gangguan jantung dan paru, kondisi anemia serta masalah sirkulasi pembuluh darah. HIF-1 $\alpha$ juga berperan penting dalam proliferasi tumor. Sebagai konsekuensi dari pertumbuhan dan perkembangan sel tumor, akan terbentuk kondisi hipoksia akibat dari penggunaan energi yang besar untuk pada sel tumor tersebut. Angiogenesis sering diinduksi dari seluler massa tumor untuk 
memenuhi kebutuhan oksigen, energi dan suplai aliran darah.

\section{Prekondisi Iskemik}

Penelitian yang dilakukan Kitagawa, menunjukkan adanya sebuah fenomena proteksi neuron di daerah hipokampus pasca oklusi arteri karotis bilateral. Fenomena penting ini melindungi neuron hipokampus terhadap jejas iskemik dan dinamakan prekondisi iskemik. Prekondisi hipoksia (hypoxic preconditioning/HPC) adalah sebuah daya toleransi tubuh terhadap iskemik fokal dan global. Prekondisi hipoksia tidak hanya melindungi otak dan jaringan lain terhadap iskemik, tetapi juga meningkatkan ketahanan terhadap tipe jejas lainnya (gambar 1). ${ }^{12}$

Prekondisi mencetuskan respon adaptif berbeda secara fundamental. Fenotip protektif singkat dapat diinduksi dalam hitungan menit dari pajanan iskemik atau stimulus prekondisi, sebagai akibat dari perubahan permeabilitas saluran ion, fosforilasi protein dan modifikasi protein post translasi lain. Mekanisme ini dikenal sebagai prekondisi cepat. Akan tetapi, toleransi iskemik merupakan mekanisme yang paling diharapkan, mekanisme ini membutuhkan aktivasi gen dan sintesis protein de novo. Mekanisme ini dikenal sebagai "prekondisi klasik". Mekanisme ini

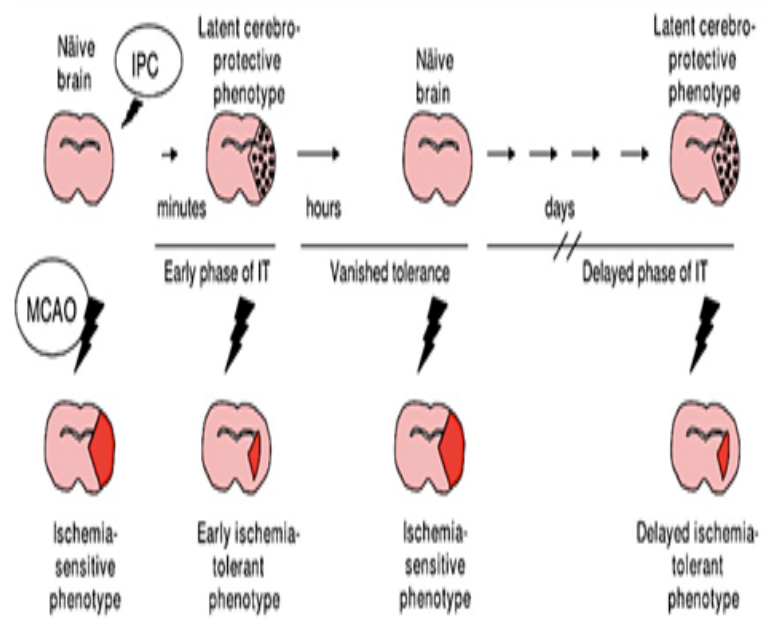

Gambar 1. Proses prekondisi iskemik.

Fenotipe sensitif iskemik muncul sebagai respon prekondisi iskemik akibat oklusi arteri serebri media. Fenotipe ini akan mengurangi kerusakan jaringan. (Dikutip dari: Gu GJ, et al. 2008) membutuhkan waktu yang lebih lama (dari beberapa jam sampai beberapa hari). Tanpa prekondisi ini, jendela atau waktu proteksi akan hilang dalam hitungan hari. ${ }^{13}$ Ekspresi aktivasi gen sangat spesifik dan berbeda untuk setiap sel, baik itu glia, neuron dan sel endotel. Implikasi klinis adalah terbentuknya gen pro survival yang dapat mengkode protein yang dapat meningkatkan ketahanan otak terhadap iskemik. Proteksi ditandai dengan meningkatnya mekanisme survival innate dan proses perbaikan endogen (seperti proliferasi dan mobilisasi sumsum tulang dan sel punca) yang memfasilitasi pemulihan fungsi otak. ${ }^{13}$ Prekondisi klasik dan stimulasi fenotip toleran terhadap iskemik melibatkan kaskade respon adaptasi terhadap stimulus spesifik. Masing-masing kaskade ditandai oleh respon gen yang memiliki sensor, transduser dan faktor transkripsi famili unik yang mengaktivasi respon tersebut dan protein efektor. Iskemik pada otak prekondisi akan mengaktivasi sebuah respon adaptif unik dan responsif. Respon adaptif ini sebenarnya merupakan respon "reprogram" terhadap iskemik (gambar 2). ${ }^{14}$

\section{Hubungan antara stroke iskemik dengan HIF- $\alpha$}

Saat terjadi proses iskemik, terdapat penurunan aliran darah serebral akibat oklusi arteri. Penurunan aliran darah serebral disertai dengan penurunan tekanan perfusi serebral. Semakin rendah aliran darah serebral maka semakin banyak jaringan otak yang mengalami kematian. Aliran darah serebral di bawah $15 \mathrm{ml} /$ menit akan membuat neuron mengalami kematian dalam hitungan beberapa menit. Proses ini terjadi di daerah sentral (core) area iskemik yang telah berubah menjadi infark. Proses ini bersifat ireversibel dan ditandai dengan pelepasan marker kematian neuron seperti glial fibrillary acidic protein yang dapat ditemukan di dalam darah dan likuor serebrospinal. Area di sekitar infark atau periinfark memiliki aliran darah relatif lebih baik dari area infark (berkisar 15-30 ml/menit). Pada area ini jaringan neuron tidak memiliki aktifitas sama sekali tetapi masih dapat dipertahankan. Area ini adalah iskemik penumbra (gambar 3). Area ini bersifat reversibel apabila ada tindakan reperfusi atau reperfusi spontan. Jika tidak terdapat reperfusi atau reperfusi terjadi pada 


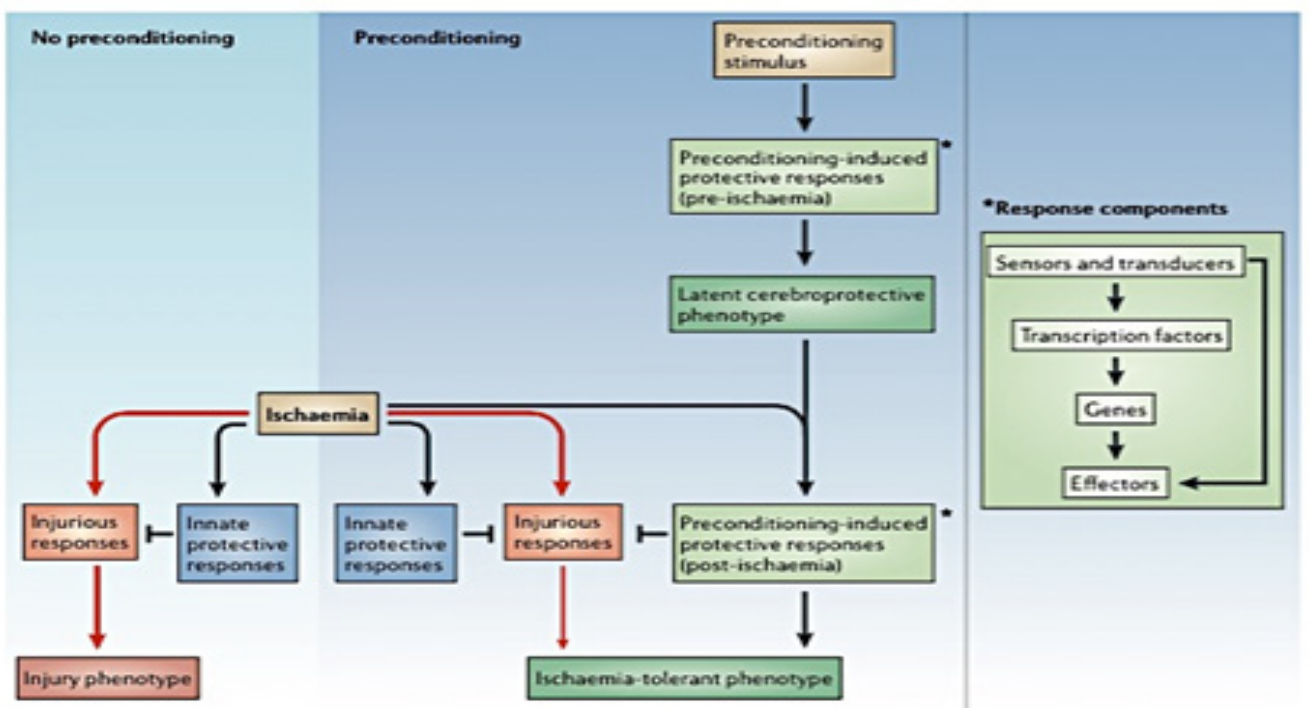

Gambar 2. Stimulus prekondisi iskemik.

Stimulus prekondisi iskemik akan menghasilkan fenotipe prekondisi iskemik yang berfungsi untuk melindungi jaringan iskemik melalui aktivasi faktor transkripsi. Aktivasi ini menghasilkan fenotipe toleran iskemik yang dapat mengurangi kerusakan jaringan.

(Dikutip dari : Rattan R, et al. 2007)

tahap lanjut, maka area penumbra akan menjadi membesar dan dapat berubah menjadi area infark (gambar 3). ${ }^{20}$

Mengikuti iskemik serebri, HIF-1 $\alpha$ membantu sel neuron untuk bertahan dalam keadaan tidak menguntungkan dan menciptakan respon adaptif pada tingkat transkripsi. Selama hipoksia, HIF$1 \alpha$ menstimulasi dan meningkatkan ekspresi beberapa gen yang terlibat dalam angiogenesis, glikolisis, transportasi glukosa, tonus vascular dan fungsi mitokondria, yang secara bersamaan menginisiasi mekanisme ketahanan sel di bawah kondisi tidak menguntungkan. Akan tetapi, HIF$1 \alpha$ juga terlibat dalam aktivasi beberapa gen seperti p53 dan BNip yang terlibat dalam apoptosis. ${ }^{16}$ Sebagai respon terhadap kadar oksigen tidak adekuat, akumulasi HIF-1 $\alpha$ akan berubah. Ekspresi mRNA HIF-1 $\alpha$ pertama sekali muncul dalam 30 sampai 60 menit pasca awitan hipoksia. Peningkatan hingga 15-17 kali lipat ekspresi HIF-1 $\alpha$ dapat dilihat 7.5 jam pasca iskemik dan tetap konsisten sampai 24 jam di area penumbra. Akumulasi HIF- $1 \alpha$ dimulai dari 1 jam pasca iskemik dan dapat muncul sampai 7 hari pasca iskemik. Induksi HIF-1 $\alpha$ dan aktivasi transkripsi gen target terjadi di area penumbra pasca iskemik. Peningkatan kadar HIF-1 $\alpha$ akan meningkatkan alirandarah,oksigendannutrisikeareapenumbra. ${ }^{16}$

\section{Efek protektif HIF-1 $\alpha$}

HIF-1 $\alpha$ berakumulasi dan menstimulasi ekspresi beberapa gen yang menginisiasi angiogenesis, eritropoesis, mempertahankan tonus vaskular, fungsi mitokondria, dan ketahanan sel pasca iskemik. Prekondisi atau inhibisi PHD merupakan

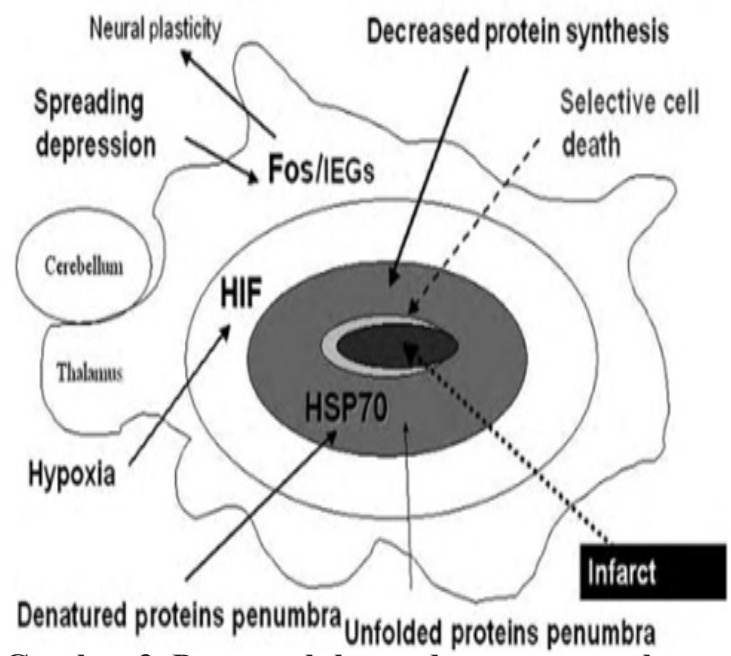

Gambar 3. Proses selular pada area penumbra. HIF diproduksi pada keadaan hipoksia

(Dikutip dari : Liu Y, et al. 2007) 
stimulus akumulasi HIF-1 $\alpha$ dan menciptakan efek proteksi terhadap kerusakan stroke iskemik. Prekondisi hipoksia hipobarik menciptakan proteksi mendalam terhadap iskemik serebral. HIF-1 $\alpha$ meningkatkan regulasi sodium-calcium exchanger-1 (NCX-1). Ada beberapa gen yang diregulasi oleh HIF-1 $\alpha$. Induksi HIF-1 $\alpha$ dan aktivasi transkripsi gen target terjadi di area penumbra pasca iskemik. Peningkatan kadar HIF-1 $\alpha$ akan meningkatkan aliran darah, oksigen dan nutrisi ke area penumbra. ${ }^{16,17}$

\section{Efek merugikan HIF-1 $\alpha$}

Walaupun di satu sisi HIF-1 $\alpha$ memiliki peranan penting dalam mekanisme neuroprotektif tetapi di sisi lain HIF-1 $\alpha$ juga memiliki peran sebagai induser apoptosis dalam stroke iskemik. HIF-1 $\alpha$ menginduksi gen $\mathrm{p} 53$ dan $\mathrm{p} 21$, yang terlibat dalam kontrol siklus sel protein p53 meregulasi gen apoptosis lain seperti PERP, NOXA, PUMA dan Bax. Aktivasi gen-gen apoptosis menyebabkan apoptosis hipoksia. LDH juga diinduksi oleh HIF-1 $\alpha$, menandakan peningkatan laktat, yang bertanggung jawab terhadap konsekuensi negative pasca iskemik serebral. ${ }^{16}$

Iskemik serebral akan menginisasi sel inflamasi. iNOS berperan dalam inflamasi selama iskemik serebral, merupakan salah satu gen target HIF-1 $\alpha$, bertanggung jawab terhadap keadaan proapoptosis. Sitokin inflamasi seperti IL-20,
IL-1 juga diregulasi oleh HIF-1 $\alpha$. Pembelahan caspase 3 juga semakin aktif, begitu juga BNIP3. BNIP dan BNIP3, keluarga Bcl2 diaktivasi oleh kondisi hipoksia. BNIP3 memiliki HRE di tempar promotor yang merupakan target langsung HIF$1 \alpha$ dan aktivasinya menyebabkan kematian sel via depolarisasi membran dan pembukaan MPTP. HIF-1 ajuga memiliki peran dalam pembentukan edema pasca stroke dengan meningkatkan ekspresi aquaporin 4 dan 9 (gambar 4). ${ }^{20}$

\section{Vascular Endothelial Growth Factor (VEGF)}

Pertumbuhan, diferensiasi dan ketahanan sel endotel diregulasi oleh VEGF. HIF$1 \alpha$ menstimulasi VEGF. Selama iskemik serebral, jaringan yang rusak mencoba untuk meningkatkan pengiriman oksigen via induksi angiogenesis melalui produksi VEGF. Ini ditandai dengan adanya peningkatan jumlah pembuluhpembuluh darah mikro di area infark. VEGF dan reseptornya diregulasi oleh HIF-1 $\alpha$ dalam hari pertama iskemik. Tidak hanya ekspresi VEGF tetapi faktor kesintasan angiogenesis lain seperti angiopoietin-2 dan insulin growth factor (IGF)-2 dan reseptornya diinduksi oleh HIF-1 $\alpha .^{18}$

VEGF (VEGF-A, VEGF-B, dan placental growth factor) berperan penting dalam perkembangan dan fungsi sirkulasi serta sistem saraf. Selain itu juga, VEGF memiliki implikasi yang luas dalam semua fase perkembangan neurovaskular berupa

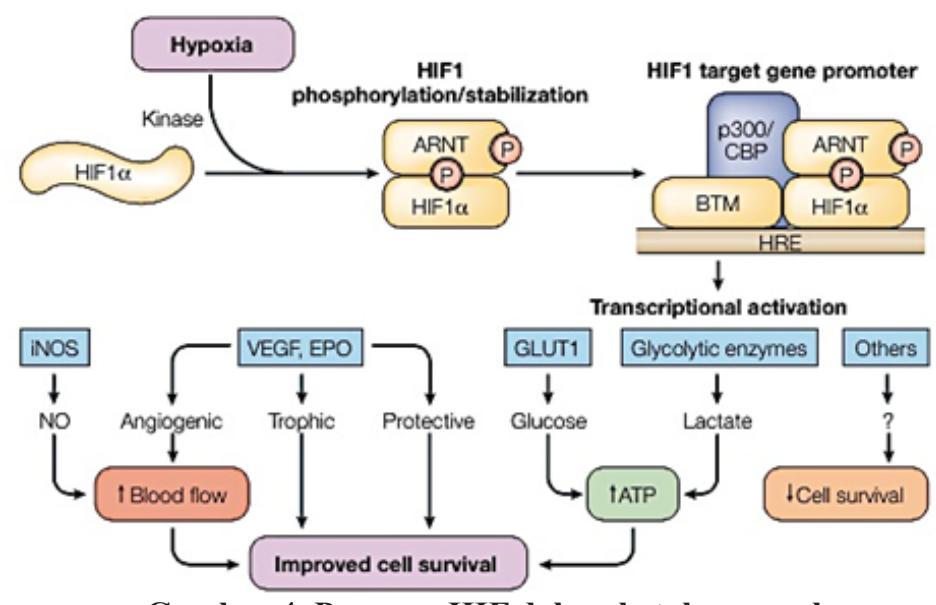

Gambar 4. Peranan HIF dalam ketahanan sel

(Dikutip dari : Vangeisson G, et al. 2008) 
vaskulogenesis, (angiogenesis dan arteriogenesis) yang terinduksi oleh kondisi hipoksia. VEGF berperan pula dalam efek protektif terhadap neuron, sehingga VEGF sangat relevan terbentuk pada kondisi stroke iskemik. ${ }^{19,20}$ Dalam sebuah penelitan didapatkan bahwa VEGF akan meningkat pada awitan awal stroke iskemik dibandingkan dengan orang normal. Peningkatan kadar VEGF pada pasien stroke iskemik secara signifikan meningkat pada hari ketiga awitan dan tubuh akan tetap mempertahankan sampai hari kesembilan puluh pasca awitan stroke. Kadar VEGF pada saat awitan stroke akut akan berhubungan dengan prognosis jangka panjang pasien stroke iskemik. ${ }^{20}$

Sebuah studilainmenunjukkan bahwa kadarserum VEGF lebih tinggi didapatkan pada kelompok stroke iskemik pembuluh darah besar (large vessel disease) dibandingkan dengan kelompok stroke pembuluh darah kecil (small vessel disease). ${ }^{20}$ VEGF akan menstimulasi neogenesis dan proses pemulihan pada pembuluh darah kolateral. Pembuluh darah koletaral merupakan pertahanan pertama jaringan iskemik yang akan menyediakan jalur alternatif untuk aliran pembuluh darah ke jaringan tersebut. Suplai pembuluh darah kolateral dalam sirkulasi otak melibatkan pembuluh darah intrakranial dan ekstrakranial. Sistem kolateral yang adekuat akan membantu menurunkan derajat keparahan stroke dan merupakan sasaran utama dalam pengobatan stroke. ${ }^{15,20}$

\section{Simpulan}

HIF-1 $\alpha$ memiliki peranan ganda, tergantung kepada durasi dan beratnya iskemik atau insult hipoksia. Semakin berat iskemik, yang ditandai dengan makin besarnya trombosis pada aliran pembuluh darah, maka semakin berat pula derajat iskemik yang terjadi. Hal ini akan mempengaruhi kadar HIF-1 $\alpha$ dalam darah. Kehilangan fungsi HIF-1 $\alpha$ di neuron mengurangi viabilitas pasca hipoksia, sedangkan kehilangan fungsi HIF-1 $\alpha$ di astrosit melindungi neuron dari kematian neuron diinduksi hipoksia. HIF$1 \alpha$ berakumulasi dan menstimulasi ekspresi beberapa gen yang menginisiasi angiogenesis, eritropoesis, mempertahankan tonus vaskular, fungsi mitokondria, dan ketahanan sel pasca iskemik yaitu VEGF.VEGF akan menstimulasi neogenesis dan proses pemulihan pada pembuluh darah kolateral.

Pembuluh darah kolateral merupakan pertahanan pertama jaringan iskemik yang akan menyediakan jalur alternatif untuk aliran pembuluh darah ke jaringan tersebut. Sistem kolateral yang adekuat akan membantu menurunkan derajat keparahan stroke dan merupakan sasaran utama dalam pengobatan stroke. Biomolekuler yang terjadi saat onset stroke iskemik akut,yaitu HIF 1 dan VEGF akan meningkatkan luaran klinis paska stroke sehingga dapat menjadi pertimbangan target pengobatan stroke fase akut di masa yang akan datang.

\section{Daftar Pustaka}

1. Yuwono S. Stroke dan penanganan terkini: Apakah kecatatan permanen atau kematian akibat stroke dapat dicegah?: Kementrian Kesehatan RI; 2016.

2. Rajamani K, Fisher M. Atherosclerosispathogenesis and pathophysiology. Dalam: Ginsberg MD, Bogousslavsky J, eds. Cerebrovascular Disease: Pathophysiology, Diagnosis, and Management, vol.2. Londodn: Blackwell Science;1998:308-18

3. De Gracia DJ, Rafols JA, Morley SJ, Kayali F. Immunohistochemical mapping of total and phosphorilated eucariotic initiation factor $4 \mathrm{G}$ in rat hippocampus following gobal brain ischemic and reperfusion. Neuroscience. 2006;139;1235-48.

4. Wang CX, Shuaib A. Critical role of microvasculature basal lamina in ischemic brain injury. Prog Neurobiol.2007;83:140-8.

5. Takasawa M, Beech JS, Fryer TD, Hong YT, Hughes JL, Igase K, et al. Imaging of Brain Hypoxia in permanent and temporary middle cerebral artery occlusion in the rat using F-18-fluoromisonidazole and positron emission tomography: a pilot study. J Cereb 
Blood Flow Metab. 2007;27:679-89.

6. Kane I, Sandercock P, Wardlaw J. Magnetic resonance perfusion diffusion mismatch and thrombolysis in acute ischemic stroke: a systemic review of the evidence to date. $\mathrm{J}$ Neurol Neurosurg Psychiatry. 2007:78:48590.

7. Baranova O, Miranda LF, Pichiule P, Gragatsis I, Johnson RS, Chaver JC. Neuron specific inactivation of hypoxia inducible factor 1 alpha increases brain injury in a mouse model of transient focal cerebral ischemia. J Neurosci. 2007;27;6320-32.

8. Lee SH, Kim YJ, Lee KM, Ryu S, Yoon BW. Ischemic preconditioning enhance neurogenesis in subventricular zone. Neuroscience, 2007;146;1020-31.

9. Sun Y, Jin K, Xie L. VEGF induced neuroprotection, neurogenesis, and angiogenesis after focal cerebral ischemia. $\mathrm{J}$ Clin Invest. 2003;111;1843-51.

10. Li Y, Dong H, Chen M, Liu J, Yang L, Chen $\mathrm{S}$ et al. Preconditioning repeated hyperbaric oxygen induced myocardial and cerebral protection in patients undergoing coronary artery by pass graft surgery: a prospective, randomized, controllled, clinical trial. J Cardiothorac Vasc Anest, 2011;25;908-16.

11. Greenberg DA, Jin Kunlin. Vascular endothelial growth factors (VEGF) and stroke. Cell Mol Life Sci.2013;70(10):1753-61.

12. Ohtaki H, Tajeda T, Dohi K, Yofu S, Nakamachi $\mathrm{T}$, et al. Increased mitochoncrial DNA oxidative damage after transient middle cerebral artery occlusion in mice. Neurosci. Res. 2008;58;349-355.

13. Landberg M, Lee J, Christensen S, Straka M, De Silva, et al. RAPID automated patient selection for reperfusion therapy; a pooled analysis of the echoplanar imaging thrombolytic evaluation trial (EPITHET) and the dufussion and perfusion imaging evaluation for understanding Stroke evolution (DEFUSE) study. Stroke. 2011;42;1608-14.

14. Straka M, Albers G, Bammer R. Real time diffusion and perfusion mismatch analysis in acute stroke. J Magn Reson Imaging. 2010;32;1024-37.

15. Giusti S, Plazas S. Neuroprotection by hypoxic preconditioning involves upregulation of hypoxia-inducible factor 1 alpha in a prenatal model of acute hypoxia. $\mathrm{J}$ Neurosci Res. 2011;22766:468-478.

16. Jeong J, Bae M, Ahn M, Kim S, Sohn T, et al. Regulation and destabilization of HIF-1 alha by ARD1 mediated acetylation. Cell. 2002;111:709-20.

17. Cheng j, Kang $X$, Zhang S, Yeh E. SUMO-spesific protease 1 is essential for stabilization of HIF-1alpha during hypoxia. Cell. 2007;131:584-95.

18. Vertegaal A, Ogg S, Jaffray E, Rodriguez M, Hay R, et al. A proteomic study of SUMO-2 target protein. J Biol Chem.2004;279:2279133798 .

19. Bruick R. Oxygen sensing in the hypoxic response pathway: regulation of the hypoxiainducible transcription factor. Genes Dev. 2003;17:2614-23.

20. Bernaudin M, Nedelec A, Divoux D, Mackenzie E, Petit E, et al. Normobaric hypoxia induceds tolerance to focal permanent cerebral ischemia in association with an increased expression of hypoxia-inducible factor- 1 and its target genes, erythropoietin and VEGF, in adult mouse brain. J cereb Blood Flow Metab. 2002;22:393-403. 